\title{
Energy retrofitting of a typical old Danish multi-family building to a "nearly-zero" energy building based on experiences from a test apartment
}

Morelli, Martin; Rønby, Leif; Mikkelsen, Svend Erik; Christensen, Maja G.; Kildemoes, Troels; Tommerup, Henrik M.

\section{Published in:}

Energy and Buildings

Link to article, DOI:

10.1016/j.enbuild.2012.07.046

Publication date:

2012

Document Version

Early version, also known as pre-print

Link back to DTU Orbit

Citation (APA):

Morelli, M., Rønby, L., Mikkelsen, S. E., Christensen, M. G., Kildemoes, T., \& Tommerup, H. M. (2012). Energy retrofitting of a typical old Danish multi-family building to a "nearly-zero" energy building based on experiences from a test apartment. Energy and Buildings. https://doi.org/10.1016/j.enbuild.2012.07.046

\section{General rights}

Copyright and moral rights for the publications made accessible in the public portal are retained by the authors and/or other copyright owners and it is a condition of accessing publications that users recognise and abide by the legal requirements associated with these rights.

- Users may download and print one copy of any publication from the public portal for the purpose of private study or research.

- You may not further distribute the material or use it for any profit-making activity or commercial gain

- You may freely distribute the URL identifying the publication in the public portal 
REVISED VERSION OF PRE-PRINT

Energy and Buildings, Available online 14 August 2012

DOI: 10.1016/j.enbuild.2012.07.046

Energy retrofitting of a typical old Danish multi-family building to a "nearly-zero" energy building based on experiences from a test apartment

Martin Morelli ${ }^{a *}$, Leif Rønby ${ }^{b}$, Svend Erik Mikkelsen ${ }^{c}$, Maja G. Christensen ${ }^{c}$, Troels Kildemoes ${ }^{d}$, Henrik M. Tommerup $^{\text {a }}$

${ }^{a}$ Department of Civil Engineering, Technical University of Denmark, Brovej - Building 118, 2800 Kgs. Lyngby, Denmark

${ }^{\mathrm{b}}$ Rönby.dk, Sturlasgade 12c, 2300 Copenhagen S, Denmark

${ }^{\mathrm{c}}$ COWI, Parallelvej 2, 2800 Kgs. Lyngby, Denmark,

${ }^{\mathrm{d}, 1}$ Ellehauge \& Kildemoes, Vestergade 48 H, 2s.tv., 8000 Århus C, Denmark

* Corresponding author:

Martin Morelli, e-mail: marmo@byg.dtu.dk; phone: (+45) 4525 1858; fax: (+45) 45883282.

Co-authors:

Leif Rønby, e-mail: leif@ronby.dk

Svend Erik Mikkelsen, e-mail: sem@cowi.dk

Maja G. Christensen, e-mail: mgch@cowi.dk

Troels Kildemoes, e-mail: tk@ekolab.dk

Henrik M. Tommerup

\footnotetext{
${ }^{1}$ Ellehauge \& Kildemoes changed name January 1, 2012 to Ekolab.
} 
REVISED VERSION OF PRE-PRINT

Energy and Buildings, Available online 14 August 2012

DOI: 10.1016/j.enbuild.2012.07.046

\section{Abstract}

The purpose of the research described in this paper was to demonstrate that an old Danish multi-family building built in 1896 could be retrofitted to a "nearly-zero" energy building. Three types of retrofit measures were implemented in a "test" apartment to obtain practical experiences. The first measure was the installation of two different types of interior insulation, specifically, an insulation component consisting of an aerogel-stone wool mixture or vacuum insulation panels. The second measure related to the retrofit of windows in which five measures were completed that consisted of applying a secondary frame, a sash mounted on the frame or to coupled frames. The third measure consisted of installing a decentralised mechanical ventilation system with heat recovery. The results showed that following the retrofit the building's theoretical energy use diminished from $162.5 \mathrm{kWh} /\left(\mathrm{m}^{2}\right.$ year) to $51.5 \mathrm{kWh} /\left(\mathrm{m}^{2}\right.$ year), corresponding to a reduction in energy use of $68 \%$. The theoretical energy use after retrofitting fulfilled the requirements for new buildings in Denmark. The practical experiences that were retained following the retrofit were that the ventilation system ought to be installed with low noise components, insulation materials must be sized and cut to fit on site, and that new windows were selected.

\section{Keywords:}

Renovation; Energy saving; Inside insulation; Window; Mechanical ventilation; Roof, Measurement; Wooden beam

\section{Introduction}

During the last decade the European Union (EU) has worked intensively to improve energy efficiency in the building sector. The primary legislative instrument through which improvements in energy performance of buildings were sought is the Energy Performance of Building Directive (EPBD), which was first introduced in 2002 [1]. In the most recent revision of the EPBD, introduced as of 2010 [2], all new buildings should be designed and constructed as "nearly-zero" energy buildings. Contrary to new buildings, the existing buildings that undergo major renovation or individual retrofitted building elements should meet the minimum energy performance requirements so far as this is technically, functionally and economically feasible. The improved energy efficiency of the building stock is expected to play a key role in meeting the EU commitment to the Kyoto Protocol in respect to the reduction of $\mathrm{CO}_{2}$ emissions, as well as to liberate EU from using fossil fuels and hereby increase EUs energy security by using renewable energy sources. It is well know that the energy use of the EU's building stock accounts for about $40 \%$ of the overall energy use of which households make up about 25\% [3]. In $200967 \%$ of the energy consumed in households was for heating as 


\section{REVISED VERSION OF PRE-PRINT \\ Energy and Buildings, Available online 14 August 2012 \\ DOI: 10.1016/j.enbuild.2012.07.046}

compared to $70 \%$ recorded in 2000 [4]. This indicates that there is a significant potential for energy savings from improvements on the energy use of households. This is supported by the average annual rate for the construction of new dwellings in EU-15 member states which is about $1 \%$ and a replacement rate of $0.07 \%$ of the existing stock [5]. An audit of 193 buildings in 7 countries taken from the EU-27 member states showed an energy use for heating varying from $31 \mathrm{kWh} /\left(\mathrm{m}^{2}\right.$ year) (Greece) to $763 \mathrm{kWh} /\left(\mathrm{m}^{2}\right.$ year) (Poland) [6]. A more detailed study of buildings built before $1945[7,8]$ from 8 EU countries located in the moderate climate zone $[9,10]$ showed that the energy use for heating ranged in value from 160 to $326 \mathrm{kWh} /\left(\mathrm{m}^{2}\right.$ year $)$; this energy usage is representative of the building described in this paper. These levels of energy use can be compared with the intent within the EU of achieving "nearly-zero" energy buildings by 2020. In 2015 new buildings constructed in Denmark will be permitted to use a yearly supplied energy of about $30 \mathrm{kWh} /\left(\mathrm{m}^{2}\right.$ year) whereas only $20 \mathrm{kWh} /\left(\mathrm{m}^{2}\right.$ year) will be allowed in 2020 [11]. For buildings built before 1945 and for which the average energy use is significantly higher than the targeted values for "nearly-zero" energy buildings of 2020, substantial energy savings can potentially be released if an economically sound approach can be established for the energy retrofitting of this building stock.

A study on the retrofitting of Belgian residential homes [12] ranked measures to be performed in three steps, specifically: (i) building envelope, (ii) mechanical installations and (iii) renewable energy sources. Other case studies completed by various European organisations [13-15] of multi-family buildings built from 1880 onwards (most buildings from around the 1960's) demonstrated that substantial energy savings up to $90 \%$ could be obtained when insulation was applied to the exterior building facade. This was readily feasible given that the buildings were built with cladding that could be easily removed and retrofitted or buildings having concrete facades not worthy of preservation. However, in instances where historical and cultural preservation of the exterior of the building facade was of interest, retrofitting the exterior was evidently not an option and the only alternative was installing insulation on the interior side of the external wall. Studies undertaken to investigate energy savings of such types of retrofits were conducted by Morelli et al. [16] in which was analysed a multi-family building built in 1930 and having brick facades which were considered preservation worthy. The results of this study indicated that, as was evident from previous studies on retrofitting with placement of insulation on the exterior of the facade, significant energy savings could also be found in this instance where the energy consumption was reduced by ca. $70 \%$, that is from $107.2 \mathrm{kWh} /\left(\mathrm{m}^{2}\right.$ year) to 30.4 $\mathrm{kWh} /\left(\mathrm{m}^{2}\right.$ year). However, it was also determined that the retrofit was not cost effective; this is a similar conclusion to 


\section{REVISED VERSION OF PRE-PRINT \\ Energy and Buildings, Available online 14 August 2012 \\ DOI: 10.1016/j.enbuild.2012.07.046}

that derived from the work reported by Kamper et al. [15] for which retrofitting measures required attaining very low energy usage levels in the range of $17.5 \mathrm{kWh} /\left(\mathrm{m}^{2}\right.$ year $)$ to $50.6 \mathrm{kWh} /\left(\mathrm{m}^{2}\right.$ year $)$.

In this paper the results from a demonstration project are presented in which the energy retrofit measures were determined for a multi-family building built in Copenhagen in 1896. The basis for undertaking the energy retrofit was for the purpose of fulfilling the "near-zero" energy performance requirements of 2015 (i.e. $30 \mathrm{kWh} /\left(\mathrm{m}^{2}\right.$ year)) by demonstrating new retrofit concepts. The work reported in this paper represents that from the planning phase that includes an assessment of the potential retrofit measures to that of the implementation phase of the retrofit measures. The measures that were subsequently selected were based on those experiences gained from different measures that were applied to a "test" apartment within the building. The project focused on retrofitting the building envelope, ventilation system and domestic hot water pipes and no other mechanical installations. The two primary objectives of the project were: (i) to install new insulation materials and mechanical ventilation systems, where the main focus was placed on the evaluation of practical implementation of these measures, and; (ii) to demonstrate that this multi-family building could be energy retrofitted to meet an energy use of about $30 \mathrm{kWh} /\left(\mathrm{m}^{2}\right.$ year $)$.

The energy use was theoretically calculated for the whole building indicating the required retrofit measures to achieve an energy use of about $30 \mathrm{kWh} /\left(\mathrm{m}^{2}\right.$ year $)$. Subsequently retrofit measures related to windows, mechanical ventilation, and inside insulation were implemented in a selected test apartment in order to determine the best course of action for the entire building renovation project. Given that inside insulation increases the risk for mould growth behind the insulation and wood decay in the wooden beams embedded in the masonry the temperature and relative humidity were measured at critical areas within the structures of the test apartment. Although it is acknowledged that in the renovation of buildings the results from hygrothermal simulations are as important as those derived for energy performance calculations, given that such results can help determine whether there is a risk of mould growth, the description of and results derived from hygrothermal simulations undertaken for this project are beyond the scope of this paper.

Information on the costs of the retrofit measures is also given. Some of the retrofit measures that were evaluated included the use of new and more expensive materials; however the economic viability of the proposed retrofit measures was not an issue that was central to this study.

\section{Retrofitting approach and calculation method}




\section{REVISED VERSION OF PRE-PRINT \\ Energy and Buildings, Available online 14 August 2012 \\ DOI: 10.1016/j.enbuild.2012.07.046}

The approach taken to complete the retrofit measures was to reduce the energy use of the building to $30.3 \mathrm{kWh} /\left(\mathrm{m}^{2}\right.$ year). This corresponded to the minimum requirements prescribed in the Danish building regulation for the construction of new residential buildings by 2015 [11]. Additionally it was the intent that the energy savings should be achieved using passive measures e.g. the installation of insulation, windows and ventilation systems and not with the use of renewable energy sources, such as the installation of solar heating or photovoltaic panels.

The first step in the implementation of this project was to calculate the energy use for the existing building and compare the theoretical energy use for heating and hot water with the measured heating energy use. The second step was to put forward all the potential retrofit measures of the building envelope and mechanical installations and thereafter calculate the expected energy savings for each measure. The third step was then to combine the individual measures with respect to the energy savings and thus evaluate whether the anticipated energy use after retrofit could be achieved. The fourth and final step was to implement the retrofit measures in a test apartment and gain practical knowledge of implementing such measures. These measures consisted of the installation of two new insulation products, as well as five different windows retrofit measures, and the installation of a mechanical ventilation system. Based on these experiences, the theoretical energy use of the retrofitted building was calculated.

The theoretical energy use of the building in respect to heating, cooling, ventilation, hot water, and mechanical installations was calculated using the software program Be10 [17], which in Denmark is used for approval of the energy use in new buildings and large renovations. The Be10 program is a one zone-model that uses a constant inside temperature of $20^{\circ} \mathrm{C}$ and monthly average values from the Danish design reference year as outside climate data. The calculations undertaken within the Be10 model were based on that specified in EN 13790 [18] as relates to method 1 on heating and cooling. However, the Be10 model includes overheating in the buildings total energy use, as the electricity use from a mechanical cooling plant is used to cool rooms when room air temperature exceeds $26^{\circ} \mathrm{C}$. In the $\mathrm{Be} 10$ model, residential buildings are considered to be used 24 hours with a load factor for people of $1.5 \mathrm{~W} / \mathrm{m}^{2}$ heated floor area and $3.5 \mathrm{~W} / \mathrm{m}^{2}$ for equipment, which were used in the calculation of the energy use. Of note is that the energy use of lighting is not accounted for in the calculation of the energy use for residential buildings. Furthermore, in the Be10 model, the calculation of energy use from different energy sources are weighted differently based on the use of fossil fuel in energy production. Energy use related to district heating was accounted for with a factor 1.0 whereas electricity was accounted for with a factor 2.5 , i.e. the need for $1 \mathrm{kWh}$ of energy for heating supplied from district heating would 


\section{REVISED VERSION OF PRE-PRINT \\ Energy and Buildings, Available online 14 August 2012 \\ DOI: 10.1016/j.enbuild.2012.07.046}

correspond to $1 \mathrm{kWh}$ whilst supplied from electricity this would be $2.5 \mathrm{kWh}$. Many assumptions are made within the program and the one-zone model is not suitable for evaluation of the indoor environment.

To estimate all heat losses in the Be10 model, detailed 2D thermal calculations were completed to determine the U- and $\Psi$-values of the building elements and assemblies before and after retrofitting.

\section{Reference building}

The case building is located in Copenhagen, Denmark and is a multi-family building built in 1896 having six stories and a full height basement below ground level. The total gross heated floor area is $2717 \mathrm{~m}^{2}$ which is divided amongst 30 apartments in three stairways (Fig. 1). The building faces an urban renewal that includes renovation of the windows, installation of outside insulation of the northeast facing end wall, and installation of mechanical ventilation in the apartments.

\subsection{Building envelope}

The facades are built of solid brick masonry having a thickness from 360-720 mm; these have been considered by the municipality as being worthy of preservation. The spandrel was $240 \mathrm{~mm}$ thick and covered with wooden sheathing (Fig. 2). The northeast end wall was unattached to neighbour buildings and $360 \mathrm{~mm}$ thick.

The windows located on the street facade were predominantly single glazed 4-light windows having a secondary glazing. The windows facing the courtyard were single glazed windows that varied between 4-and 6-lights windows. The un-insulated roof was a typical roof as built in Copenhagen (Fig. 1a). The floor divisions were constructed with wooden beams and clay pugging and the floor divisions towards the unheated attic and basement were un-insulated. Table 1 provides the calculated $U$ - and $\Psi$-values for the building envelope before and after retrofitting. The negative $\Psi$ values arise from the definition of the building envelope areas. In some instances the U-values include the linear thermal transmittance for the assembly; however, if the U-values include too large a heat loss through the assembly, this was then corrected by the negative $\Psi$-value.

\subsection{Installations}

The building employed central heating which was produced from a heat exchanger located in the basement of the building that extracted energy from a distributed district heating system. The apartments were naturally ventilated by opening windows, through infiltration and with ventilation ducts located in the kitchen and bathroom; however, many 


\section{REVISED VERSION OF PRE-PRINT \\ Energy and Buildings, Available online 14 August 2012 \\ DOI: 10.1016/j.enbuild.2012.07.046}

of the ducts were blocked and thus not operational. The installations were not assessed in respect to their operability and were assumed to be in average working condition for a building built in that period; e.g. the heating pipes were assumed to be insulated with $20-30 \mathrm{~mm}$ insulation.

\subsection{Energy consumption}

The average measured energy use for heating and hot water in the period $2007-2009$ was $155.5 \mathrm{kWh} /\left(\mathrm{m}^{2} \cdot\right.$ year); these values were obtained from the heating accounts and climate corrected. In Table 2 information is given on the energy use of the case study building as well as the energy use for heating and hot water. The energy use was not measured for the building but was calculated using the Be10 model as previously described. However, the difference of $9.5 \mathrm{kWh} /\left(\mathrm{m}^{2}\right.$ year) between the building's energy use $\left(162.5 \mathrm{kWh} /\left(\mathrm{m}^{2}\right.\right.$ year $\left.)\right)$ and the energy use for heating and hot water (153.0 $\mathrm{kWh} /\left(\mathrm{m}^{2}\right.$ year $\left.)\right)$ is primarily derived from the electricity used by the pumps for heating and circulation of hot water. Of note is that the electricity for lighting was not accounted for in the calculation of the building's overall energy use. The difference between the measured and calculated energy use for heating and hot water was about $2 \%$, even though several factors influence the energy use of the building e.g. different interior and exterior climate data, assumptions of the input parameters in the calculation model, and use patterns of the building. The project did not allow for detailed investigation of the existing building, for which reason the calculated energy use was not adjusted to the measured but compared to be on the same par.

\subsection{Test apartment and energy saving measures}

The first objective of the project was to evaluate different retrofit measures that had been implemented in the test apartment before determining the specific retrofit measures that would be implemented for the overall building retrofit program. The location of the test apartment in relation to the entire building is given in Fig. 1, and in Fig. 3 the retrofit measures are identified. These retrofit measures include two related to the installation of insulation materials, five measures focused on window retrofitting or replacement, and one measure related to the installation of a decentralised mechanical ventilation system incorporating heat recovery. Four of the five retrofit measures undertaken on windows are shown in Fig. 3 as one window was mounted at the ground floor level.

\subsubsection{Installation of insulation}




\section{REVISED VERSION OF PRE-PRINT \\ Energy and Buildings, Available online 14 August 2012 \\ DOI: 10.1016/j.enbuild.2012.07.046}

The insulation materials used for placement on the interior of the walls and in window reveals were either the Aerowolle or the Vacupor NT products. The Aerowolle product consists of a combination of aerogel and stone wool fibres which gives the product a thermal conductivity of $0.019 \mathrm{~W} /\left(\mathrm{m}^{2} \cdot \mathrm{K}\right)$. Whereas the Vacupor NT product is a vacuum insulation panel having a thermal conductivity of $0.005 \mathrm{~W} /\left(\mathrm{m}^{2} \cdot \mathrm{K}\right)$ for a thickness of $20 \mathrm{~mm}$ under $1 \mathrm{mbar}$ pressure measured as a centre value; at atmospheric pressure the thermal conductivity of the Vacupor NT product is $0.019 \mathrm{~W} /\left(\mathrm{m}^{2} \cdot \mathrm{K}\right)$.

As is evident in Fig. 3, the Aerowolle product was applied on two wall sections to the interior portion of the exterior wall. This permitted measuring the development of the relative humidity and temperature in the wooden beams and behind the insulation installed on the inside of the $360 \mathrm{~mm}$ thick end wall; this is the same thickness as the wall where the most critical wooden beam is encastered ( $6^{\text {th }}$ floor). The sensors for measuring the temperature and relative humidity at the beam end were placed into the end of the beam by boring a hole along the end of the beam to a depth that would place the sensors in proximity to the beam end. This was completed for one reference beam for which the wall had not been insulated and two other beams having an insulated wall above and below the beam. The sensors placed behind the insulation were milled into the existing wall, and placed approximately $1 / 3$ and $2 / 3$ up the height of the wall. For those temperature measurements taken at the reveals and spandrels, the sensors were placed in the middle of the surface in different layers of the structure. One window reveal was insulated with the Aerowolle product and one with the Vacupor NT product to permit a comparison between the performances of either of these two insulation products at the window reveal.

\subsubsection{Retrofit or installation of new windows}

As was previously indicated, five different window related retrofit measures were considered; these are identified in Table 3. The three first window retrofit measures (1-3) consisted of retrofitting the existing windows and the last two measures (4-5) were replacing the existing windows with new ones. Shown in Fig. 4a is a retrofitted window (Window 2) as seen from the exterior of the building; all the windows had appearances similar to the existing windows as shown in this figure.

Window 1 was a retrofitting measure of the existing single glazed window in which a secondary frame was applied as shown in Fig. 4b but having double glazing. In Fig. 5a a horizontal section of the frame and casement illustrates the 
REVISED VERSION OF PRE-PRINT

Energy and Buildings, Available online 14 August 2012

DOI: 10.1016/j.enbuild.2012.07.046

assembly for Window 1 and in which the original window frame is marked with white whereas the secondary frame is the dark grey area, which was installed onto the original frame. However, on the secondary frame an extra glazing was installed (light grey) at a minimum distance of $20 \mathrm{~mm}$ between the two glazing surfaces (pane 2 and 3 in Fig. 5a);

hence, the two panes in the secondary frame function as a glazing unit. The outer glazing (1) was a normal pane and the two inner panes (2 and 3 ) both had Low-E coatings towards the outside. This window can also be equipped with an insulating and reflective curtain in the cavity between the original frame and the secondary frame which could improve the energy saving potential given that $75 \%$ of the heating degree-days in Denmark are in darkness.

Window 2 as shown in Fig. 4 was a retrofitting of the existing window in which a traditional secondary frame with a Low-E coated glazing was applied. The design for Window 2 was similar to that of Window 1 but did not include a third pane as shown in Fig. 5a.

Window 3 was renovated but instead of a secondary frame a sash with a $4 \mathrm{~mm}$ tempered low-E coated glazing (Optoglas) was installed directly on the casement using a special fitting. Fig. 5b shows the corner of the casement with the installed glazing. The difference between this window and the previously described windows was that the newly installed glazing would always be fixed to the casement and thereby make up for a glazing unit that was air tight whereas the secondary frames would open to the inside and make the cavity more greatly exposed to humid room air entering the cavity and pose a risk of mould growth and condensation.

Window 4 was a newly installed coupled window with a single pane and a glazing unit whereas Window 5 was a new coupled window with two single panes. The design of the window structures are shown in Fig. $6 a$ where pane 2 was either a glazing unit or single pane for Window 4 or Window 5, respectively, and in Fig. $6 \mathrm{~b}$ is shown the newly installed window 4 seen from the interior.

Window 4 had a krypton-filled glazing unit where the inner pane was with a low-E coating as was the single outer pane. Window 5 was a new window where the manufacture tried to imitate the details of the original window for which the inner pane had a low-E coating. 
REVISED VERSION OF PRE-PRINT

Energy and Buildings, Available online 14 August 2012

DOI: 10.1016/j.enbuild.2012.07.046

The energy data for the seven different windows provided in Table 3 was calculated for a 4-light window of $1.1 \times 1.6$ $\mathrm{m}$. The window net energy gain $\left(\mathrm{E}_{\mathrm{ref}}\right)$ to the building, as given in Eq. 1, provided values for which a positive value for $E_{\text {ref }}$ indicated a supply of energy, and a loss of energy was detected from negative values of $E_{\text {ref }}[19]$.

$\mathrm{E}_{\mathrm{ref}}=196.4 * \mathrm{~g}_{\mathrm{w}}-90.36 * \mathrm{U}_{\mathrm{w}}$

where

$\mathrm{E}_{\text {ref }} \quad$ : net energy gain from the window $\left[\mathrm{kWh} /\left(\mathrm{m}^{2}\right.\right.$ year $\left.)\right]$

$\mathrm{g}_{\mathrm{w}} \quad$ : solar energy transmittance for the window [-]

$\mathrm{U}_{\mathrm{w}} \quad$ : coefficient of heat transmittance for the window $\left[\mathrm{W} /\left(\mathrm{m}^{2} \mathrm{~K}\right)\right]$

\subsubsection{Retrofit of mechanical ventilation system}

The decentralised balanced mechanical ventilation system incorporating a heat recovery unit (Nilan Comfort 250) had a maximum ventilation rate of $250 \mathrm{~m}^{3} / \mathrm{h}$, and the unit was able to be connected to the kitchen exhaust. In apartments with a very tight building envelope the exhaust hood in forced operation can produce problems such as noise and negative pressure in the apartment such that doors can be difficult to open. According to the information provided in the Danish building regulations [11] the ventilation in the apartment can be demand controlled (DCV), which means that the ventilation rate is variable and allowed to be lowered below the minimum requirements depending on the usage of the room. In this way energy can be saved by reducing the ventilation rate, however the DCV rate must be at least or greater than $0.31 /\left(\mathrm{s} \mathrm{m}^{2}\right)$. This corresponded to a ventilation rate of $90 \mathrm{~m}^{3} / \mathrm{h}$ for this specific apartment nevertheless the ventilation rate must at least be able to increase to a minimum of $126 \mathrm{~m}^{3} / \mathrm{h}$ for the kitchen $\left(72 \mathrm{~m}^{3} / \mathrm{h}\right)$ and bathroom (54 $\mathrm{m}^{3} / \mathrm{h}$ ) under normal operating conditions. The ventilation rate should also be able to be accelerated to $198 \mathrm{~m}^{3} / \mathrm{h}$ at maximum ventilation from the kitchen exhaust in forced operation $\left(144 \mathrm{~m}^{3} / \mathrm{h}\right)$ and bathroom.

Although in the initial retrofit measures the inlet and outlet ventilation conduits went through the wall, ultimately these ventilation system conduits should go through the roof. In this apartment, the fresh air inlet was located in the bedroom and living room whereas exhaust ducts were located in the bathroom and kitchen (Fig. 3).

\section{Experiences derived from test apartment}

\subsection{Inside insulation}




\section{REVISED VERSION OF PRE-PRINT \\ Energy and Buildings, Available online 14 August 2012 \\ DOI: 10.1016/j.enbuild.2012.07.046}

The installation of interior insulation on the wall assembly, if not properly installed, can be a source for mould growth between the insulation and the wall substrate to which it is affixed. This is of particular importance when installing insulation on brick masonry walls as compared to walls made of concrete given the large capacity for moisture uptake and retention of brick masonry walls. The accumulated moisture in brick masonry walls can be a critical factor in the formation of mould. The installation of insulation on the interior of the wall assembly can also lead to moisture problems in the wooden support beams of the floor that are encastered in the facades. This, however, depends on the degree of exposure of the masonry walls to wind driven rain [20] or rising damp. Therefore before applying the insulation on the interior walls, the walls were first cleaned so no organic material was present on the wall. It was found that when working with the Aerowolle product it was reasonably easy to work with but the Aerowolle product could not take up any deviations on the surface of the wall. Consequently, the preparation to ensure that the wall surface was relatively smooth was very important so that the applied insulation also likewise provided an even, flat surface. Furthermore, from a practical stand point it was important to try dismantling the stucco ceiling border trim as these should be re-established on the new interior wall surface. In this case it was difficult to disassemble the stucco ceiling border trim without destroying it and only 1 out of 5 meters could be reused.

The window reveals were insulated with $20 \mathrm{~mm}$ deep Aerowolle (Fig. 7a) or Vacupor NT (Fig. 7b). It was found that the gap behind the reveal panel did not fit the $20 \mathrm{~mm}$ insulation material and the size of the window opening was thus reduced. This also influenced the spandrel panel which as a consequence had to be adjusted to the new window size. The Vacupor NT insulation product constitutes a vapour barrier itself but to install the Vacupor NT to the window and the inside Aerowolle insulation an additional vapour barrier was installed to complete the vapour tight layer.

In comparison to the Aerowolle product, which was easy to work with given that it could be cut to size on site and affixed to the wall with an adhesive, the Vacupor NT product was a challenge to work with. Specifically, the Vacupor NT product needed to be ordered in specific sizes given that no on site changes could be made if incorrect sizes were delivered. In this case the measurements of the panel size were made before dismantling the reveals which involved too small Vacupor NT panels. Secondly, the material needed special care as the panels were easily punctured thereby losing their insulation value. Given both these factors, the installation of the Vacupor NT panel products was difficult in particular in the upper reveals (Fig. 7b). 


\section{REVISED VERSION OF PRE-PRINT \\ Energy and Buildings, Available online 14 August 2012 \\ DOI: 10.1016/j.enbuild.2012.07.046}

\subsection{Temperature and relative humidity measurements}

The end parts of the wooden beams that support the floor are the critical part of the load bearing structure as there is a risk for deterioration if the beam ends are exposed to high relative humidity [21] for prolonged periods of time. At the beginning (November 1) of the test trials when temperature and relative humidity $(\mathrm{RH})$ measurements were first recorded, the $\mathrm{RH}$ in the beam end was 75\% RH and after 200 days (May 20) dropped to ca. 60\% RH. These RH values were about $5-10 \% \mathrm{RH}$ higher as compared to the reference measurement. A RH below $75 \%$ does not pose a risk for the durability of the beam end [22]. However, these measurements were performed in a northeast facing wall that received, given its orientation and location on the building (between ground and first floor), a limited amount of wind driven rain and direct exposure to sunlight. It is understood that in brick faced buildings, the degree of moisture penetration to inboard elements of the wall is directly related to the degree of water deposition due to wind-driven rain and hence has a significant influence on the expected durability of the wooden beam [20].

Provided in Fig. 8 are the values for the temperature and RH measurements behind the inside insulation and in the room as of November 1, 2010 to May 20, 2011. Notably, in the period between November and May, the RH in the room ranged from $40 \%$ to $55 \% \mathrm{RH}$; this was slightly lower than the typical values for the interior of Danish homes of this type of construction as given in [23] and similar to the values obtained by measurements in 115 Danish dwellings [24].

In respect to the RH, it is evident from Fig. 8 that an initial value of $85 \% \mathrm{RH}$ was recorded and that subsequently the $\mathrm{RH}$ decreased to $80 \%$; it is also evident that when the temperature increased the RH dropped below $75 \%$. It must be noted that one measurement point located $1 / 3$ up the height of the wall remained constant at $95 \%$; this RH value was determined to be an error in measurement and has not been included in Fig. 8. The high RH values at the beginning could be due to built in moisture from mounting the sensors. The mould growth depends on several factors where the most important are temperature, $\mathrm{RH}$ and exposure time. Based on the Isopleths information provided in [25] a risk for mould growth could be present when the temperature is around $10^{\circ} \mathrm{C}$ and the $\mathrm{RH}$ is $85 \%$; in such instances under these conditions the germination time is about 2 days. However, there were no visible signs of mould growth on the wall after dismantling the Aerowolle product, which was also documented through Mycometer surface test for mould growth. Nonetheless, in the ground floor apartment located at street level and in which the Aerowolle product was installed directly onto wallpaper, the results of a Mycometer surface test indicated extensive mould growth. 


\section{REVISED VERSION OF PRE-PRINT \\ Energy and Buildings, Available online 14 August 2012 \\ DOI: 10.1016/j.enbuild.2012.07.046}

For the window reveals only the temperature was measured, which showed almost the same temperature drop over the two insulation materials; however, the temperature drop was obtained at different climate conditions. For the Vacupor NT product, the temperature difference between the indoor and outdoor climate was $18^{\circ} \mathrm{C}$, and that for the Aerowolle product was $23^{\circ} \mathrm{C}$. This therefore indicates a comparatively better thermal performance for the Vacupor NT as compared to that of the Aerowolle product.

\subsection{Windows}

The five sets of window retrofit measures investigated showed energy savings up to about $80-90 \%$ based on the net energy gain compared with the two reference windows; this information is given in Table 3 . Window 1 and Window 4 , both with three panes, were the best performing measures having a net energy gain of $-24 \mathrm{kWh} /\left(\mathrm{m}^{2}\right.$ year $)$ and -21 $\mathrm{kWh} /\left(\mathrm{m}^{2}\right.$ year) respectively. Window 1 had higher energy transmittance due to the single glazing and hard low-E coating as compared to Window 4 with a double glazing unit having soft low-E coating. The worst performing window retrofit measure of the five measures was Window 3 which had the installed sash on the casement and provided a net energy gain of $-72 \mathrm{kWh} /\left(\mathrm{m}^{2}\right.$ year $)$.

The surface temperatures of the windows were measured using thermographs shown in Fig. 9. Window 1 and 4 had the highest surface temperature as was expected given that their respective U-values had the same magnitude. Window 2 $\left(\mathrm{U}=1.62 \mathrm{~W} / \mathrm{m}^{2} \mathrm{~K}\right)$ and Window $3\left(\mathrm{U}=1.76 \mathrm{~W} / \mathrm{m}^{2} \mathrm{~K}\right)$ also had comparable $\mathrm{U}$-values but the surface temperatures were very different where Window 2 performed better but had also a lower U-value. The surface temperature of Window 3 was almost the same as for the single glazed reference window.

For the windows it was possible to obtain prices for retrofitting the existing windows or installing new windows. The prices including of VAT given in Table 3 were for a 4-light window based on the price if all windows in the building should be retrofitted. However for Window 5 only the price for producing the actual installed window was obtained, which was among the most expensive windows. It is evident from the price and net energy gain that Window 4 was the best retrofit measure where the largest energy saving for least cost was achieved; however the selection of window glazing was later optimised to improve the daylight and net energy gain. Furthermore Window 4 with a coupled frame posed least or no risk for the formation of condensation in the cavity between the glazings as it was single frame unit. 
REVISED VERSION OF PRE-PRINT

Energy and Buildings, Available online 14 August 2012

DOI: 10.1016/j.enbuild.2012.07.046

\subsection{Mechanical ventilation}

The experiences with installing a decentralised mechanical ventilation system lead to two general issues: (i) installation of ducts, and; (ii) noise generation. The ventilation unit was installed in the bathroom for which the inlet and exhaust ducts are shown in Fig. 3. The measured ventilation rates and the building regulation requirements for the test apartment are given in Table 4 at three operational levels, specifically: the minimum ventilation rate (level 1) which was the DCV rate at low or no occupancy; the minimum increased ventilation rate (level 2) which was accelerated normal operation in the presence of high moisture content, and; the minimum increased ventilation rate and forced operation of the exhaust hood (level 3). As shown in Table 4, and when comparing the measured with the required ventilation rates from the building regulation, it was seen that there was no problem in increasing the demand controlled ventilation rate when a need for more ventilation was present. The total measured ventilation rates were assessed to be sufficient for the test apartment with about $10 \%$ deviation for level 3.

The first issue was the installation of the ducts in the test apartment that was built in 1896 and evidently not designed for accommodating mechanical ventilation. Furthermore the space under the ceiling was limited even though the room height was ca. $2.5 \mathrm{~m}$; however, the top of the windows were about $20 \mathrm{~cm}$ below the ceiling. In Fig. 10 is shown how the final installation was carried out as the initial installation of the $125 \mathrm{~mm}$ diameter ducts was not deemed acceptable and therefore was reinstalled.

The second issue was the level of noise from the air handling unit. The main source for noise was detected from the ventilation unit and not the vent. The measured noise level values are given in Table 5; these levels should be below 30 $\mathrm{dB}(25 \mathrm{~dB}$ noiseless $)$ [11].

Measurement of $\mathrm{CO}_{2}$ levels in those apartments without mechanical ventilation showed higher $\mathrm{CO}_{2}$ concentrations than in the test apartment in which mechanical ventilation was present. However, the windows of the test apartment were often opened and therefore, the usefulness and efficacy of the mechanical ventilation system was difficult to verify.

\section{Whole building retrofit}

The second objective of the energy retrofit was to reduce the energy use of the building to $30.3 \mathrm{kWh} /\left(\mathrm{m}^{2}\right.$ year). In the planning phase many different measures were considered regarding modifications to the building envelope and 


\section{REVISED VERSION OF PRE-PRINT \\ Energy and Buildings, Available online 14 August 2012 \\ DOI: 10.1016/j.enbuild.2012.07.046}

mechanical ventilation system, these measures are provided in Fig. 11 for the building envelope and Fig. 12 for the mechanical equipment. In Fig. 11 and Fig. 12 are shown the theoretical calculated energy savings that could be obtained for the respective proposed retrofit measures and the theoretical energy use of the building after implementation of the different measures.

In respect to retrofit measures to be made to the building envelope, it was seen from a review of the information, that the most effective measures were new window installation, the installation of insulation on the walls, and a new highly insulated roof structure (incorporating $350 \mathrm{~mm}$ insulation). In the project it was planned replace the existing roof with a new roof and convert the previously unheated attic to dwellings, thus the heat loss to the attic was eliminated and the heated floor area increased by $455 \mathrm{~m}^{2}$. If only a new highly insulated roof structure was installed the energy savings would not be significant as shown in Fig. 11 as measure E2B.

Five ventilation retrofit measures were considered as part of the retrofit of the mechanical equipment. Two ventilation systems were considered: (i) centralised system, and; (ii) decentralised system. Either of these systems could be chosen with a DCV control. The largest energy savings were achieved with the DCV system. This was due to the reduced ventilation rate independent of the ventilation unit. A combination of three ventilation systems was also assessed; thus each stairway had one ventilation system. Two stairways were chosen to have centralised units with either DCV or not and one stairway had decentralised units with DCV.

Amongst all the individual retrofit measures proposed eight were chosen to be implemented. These were:

(i) Installation of $250 \mathrm{~mm}$ insulation at the exterior end wall of the building

(ii) Window with coupled frame with a low-E single glazing to the outside and a glazing unit with low-E coated pane to the inside. The outer and inner panes had also a high light transmittance due to a low content of iron in the panes. The net energy gain was $-18 \mathrm{kWh} /\left(\mathrm{m}^{2}\right.$ year $)$ based on a U-value of 1.03 $\mathrm{W} /\left(\mathrm{m}^{2} \mathrm{~K}\right)$, g-value of 0.38 and a light transmittance of 0.43

(iii) Three ventilation strategies were implemented in the different stairways; (i) centralised controlled, (ii) centralised DCV and (iii) decentralised DCV all with high heat recovery of approximately $85 \%$, low specific fan power from $1 \mathrm{~kJ} / \mathrm{m}^{3}$ air to $1.16 \mathrm{~kJ} / \mathrm{m}^{3}$ air and a very air tight building corresponding to passive house standard (infiltration: $0.061 /\left(\mathrm{s} \mathrm{m}^{2}\right)$ ) 
REVISED VERSION OF PRE-PRINT

Energy and Buildings, Available online 14 August 2012

DOI: 10.1016/j.enbuild.2012.07.046

(iv) The floor division to the basement was completely renovated and $120 \mathrm{~mm}$ insulation was placed between the beams

(v) Walls and spandrels were insulated on the wall interior using $40 \mathrm{~mm}$ Aerowolle

(vi) Window reveals were insulated with $20 \mathrm{~mm}$ Aerowolle

(vii) Domestic hot water pipes were insulated with $40 \mathrm{~mm}$ insulation

(viii) New roof dwellings with highly insulated roof were installed with an average depth of insulation of 350 $\mathrm{mm}$.

The combination of energy saving measures reduced the theoretical energy use of the building to $51.5 \mathrm{kWh} /\left(\mathrm{m}^{2}\right.$ year). In Fig. 13 the calculated energy use for the building as well as heating and hot water is given but also that measured before retrofitting. The result meets the requirements for new residential buildings in 2010 but not the energy use requirements in 2015 for similar new buildings which is $30.3 \mathrm{kWh} /\left(\mathrm{m}^{2}\right.$ year $)$. The theoretical energy savings obtained in the building with only passive measures was $68 \%$.

The costs for the eight planned retrofit measures amounted to $€$ 2'028'340 (including VAT and 15\% fee), where the retrofit costs were evenly distributed between measures improving the existing building (i-vii) and the new roof dwellings (viii). The cost for implementing the measures to improve the existing building was $366 € / \mathrm{m}^{2}$ of existing heated floor area, whereas the costs for a new roof for the dwellings was $2272 € / \mathrm{m}^{2}$ heated floor area of new dwellings. In this renovation it is planned to build new roof dwellings, where the sale of the dwellings can then be used to cofinance the energy retrofitting measures.

\section{Discussion}

The energy retrofitting of older multi-family buildings of cultural or historical interest is challenging and presents limitations on what can be achieved; as well, the viability of such retrofits should preferably be addressed from the beginning of the planning phase. In those instances where the aim of the retrofit project is to attain a "nearly-zero" energy building it is important that the building envelope is well insulated before optimising the operation of mechanical installations such as the ventilation with heat recovery. A well insulated building envelope and mechanical ventilation with heat recovery is sufficient to fulfil the requirements for new buildings in Denmark, however, it is still far from achieving the project aim of attaining a "nearly-zero" energy building. The energy use of $51.5 \mathrm{kWh} /\left(\mathrm{m}^{2} \mathrm{year}\right)$ for the retrofitted multi-family building was theoretically calculated using the program Be10. Different studies [26-28] have shown a large discrepancy between the predicted and actual energy use in buildings, where, for example, in multi- 


\section{REVISED VERSION OF PRE-PRINT \\ Energy and Buildings, Available online 14 August 2012 \\ DOI: 10.1016/j.enbuild.2012.07.046}

family building in Switzerland [26] it has been found that the actual energy use was 50\% higher than that predicted.

One of the reasons for this discrepancy in energy use was because of the inhabitants' behaviour. In the Be10 program a well defined use pattern is given, however Gram-Hanssen [29] found that the energy use could more than triple due to the inhabitants' behaviour and pattern of use of the heating system.

In this study insulation placed on the interior portion of walls is shown to be very important in respect to energy use as it accounts for $20 \%$ of the overall calculated energy savings. However, an evident drawback when placing insulation on the interior of the assembly is the loss of living space. There is also the potential risk to the exterior wall surface that would result from more severe climate exposure conditions brought about by a change in the moisture balance of the wall; depending on the response of the wall to these new conditions, additional maintenance costs might be incurred. However, there is also the risk for mould growth on the wall behind the insulation, but evidently retrofit measures that generate risk for mould growth or decay are unacceptable measures. Therefore, when the interior insulation is installed in all the apartments, the temperature and relative humidity will be measured in the most critical wooden beams embedded in the facades of the top two floors (oriented towards west and south-west), so that any decay development can be detected. Compared to the growth of mould behind the interior insulation which may develop relatively rapidly, it is important to undertake inspections of the surfaces before installing the insulation.

For the individuals making use of the building, the loss of living space is perhaps the most crucial aspect but this can be mitigated by using new materials having lower thermal transmittance values that would in turn permit using an insulation product with a reduced thickness. The use of the Vacupor NT product is of interest given its reduced thickness, but the experiences gained in this study with installation of these vacuum insulation panels suggests that it is not readily applicable for renovation. This is because the walls of rooms and window openings all vary in size and given that the Vacupor NT product is prefabricated, it cannot be cut to fit on site and hence cannot be practically installed. In contrast, the use and installation of the Aerowolle product was very practical and could be readily adjusted. However for the moment, this product is very costly as it is a new product and not yet readily available given its limited production. Based on the experiences gained from the installation of these products in the test apartment, the products used in retrofitting measures must be capable of being modified at the construction site. As well, it was evident that applying insulation to the interior of the assembly makes the window opening deeper and therefore the placement and selection of windows must be optimised for daylight and energy savings as in this case study, they also account for $20 \%$ of the calculated energy savings. The results from a review of retrofit measures on windows indicated that of the five different measures suggested the same degree of performance could be expected for the retrofitted as compared to the 


\section{REVISED VERSION OF PRE-PRINT \\ Energy and Buildings, Available online 14 August 2012 \\ DOI: 10.1016/j.enbuild.2012.07.046}

new window options. Given the cost of retrofitting existing windows, it is shown that the installation of new windows is a less expensive option as compared to the retrofitting of existing windows.

The reduced energy loss through the retrofitted building envelope suggested that the tightness of the building was improved to a passive house standard. In this case study it was expected that the infiltration rate was $0.061 /\left(\mathrm{s} \mathrm{m}^{2}\right)$. The air tightness for the building is expected to be obtained through installation of new windows, renovated floor division to the basement and roof structure. These measures will help improve the air tightness of the building envelope by allowing an air/vapour barrier to provide continuity at all transitions. The improved degree of air tightness of the building also increases the efficiency of the mechanical ventilation from which $20 \%$ of the calculated energy savings is obtained. Drawbacks of the use of a mechanical ventilation system can be from noise generation and negative pressure in the apartments, however, the negative pressure often occur through poor design. The pressure in the apartment should be equalised through the leaky floor divisions and openings under the doors. To avoid noise generation more silent decentralised ventilations units will be installed in the apartments. Nonetheless, an improved thermal indoor environment can be achieved where the temperatures are more even and the concentration of $\mathrm{CO}_{2}$ is reduced. In the test apartment where the windows were often opened, low levels of $\mathrm{CO}_{2}$ concentration were measured which indicates a need for demand controlled ventilation so the ventilation rate can be adjusted down to a minimum. The aesthetics of the installed ventilation ducts can be a problem as the apartments were not prepared for this type of installation when they were first built over a hundred years ago.

This case study did not focus on the use of mechanical equipment for the production of heat or domestic hot water which if implemented, would reduce the calculated energy use of the building closer to the targeted energy use of 30.3 $\mathrm{kWh} /\left(\mathrm{m}^{2}\right.$ year $)$. Otherwise, implementation of renewable energy sources or more extreme passive measures for the building envelope are needed. As the intent of the EU is to focus on the implementation of renewable energy sources through the EPBD, it might not be necessary to energy retrofit the building to a "nearly-zero" energy building if the delivered energy is from renewable energy sources. In such cases it will be more efficient to install larger energy plants instead of retrofitting all individual buildings to "nearly-zero" energy buildings. How much the building must be retrofitted should be adjusted to the energy price for delivered energy using, e.g., the cost of conserved energy presented in $[30]$.

\section{Conclusion}




\section{REVISED VERSION OF PRE-PRINT \\ Energy and Buildings, Available online 14 August 2012 \\ DOI: 10.1016/j.enbuild.2012.07.046}

A case study was presented on the energy retrofit measures undertaken on a multi-family building built in 1896 and deemed of cultural or historical importance. The results of this study indicate that it is difficult to attain a "nearly-zero" energy building without using renewable energy sources. However, it was shown that through the implementation of practical set of passive retrofit measures, such as the installation of insulation on the interior or the refurbishment or installation of new windows, the theoretical energy use can nonetheless be reduced by $68 \%$ as compared to the theoretical energy use prior to the retrofit. It is also understood that new technologies are needed to attain the reduction in energy use required to meet the objective of this study; retrofit the building so the energy use is "nearly-zero".

The project is currently on-going and several retrofit measures are being implemented during 2012. It is also apparent that for any future energy retrofitting projects, consideration must be given to determining an approach that would permit optimising the choice of building envelope retrofit measures before retrofitting installations are completed or applying renewable energy systems.

\section{Acknowledgments}

The information presented in this paper was obtained from work on the project entitled: "Development and 1:1 demonstration of concepts for renovation of older multi-family buildings to low energy class 1 " that was funded by the Danish Energy Agency under the Energy Technology Development and Demonstration Programme (EUDP) and reported in [31]. The financial support of 2'731'150 DKK (367'584€) from the Danish Energy Agency is gratefully acknowledged. The project team consisted of DTU Civil Engineering, COWI, rönby.dk, Ellehauge and Kildemoes, Rockwool, Exhausto and MT Højgaard.

\section{References}

[1] European Union, Directive 2002/91/EC of the European Parliament and of the Council of 16 December 2002 on the energy performance of buildings, Official Journal of the European Communities, 4/1/2003, Brussels, Belgium, (2002). [2] European Union, Directive 2010/31/EU of the European Parliament and of the Council of 19 May 2010 on the energy performance of buildings (recast), Official Journal of the European Union, 18/06/2010, Strasbourg, France, (2010).

[3] European Commission, EU energy and transport in figures - statistical pocketbook 2010, European Union, Luxemburg, 2010, ISBN 978-92-79-13815-7. 


\section{REVISED VERSION OF PRE-PRINT \\ Energy and Buildings, Available online 14 August 2012 \\ DOI: 10.1016/j.enbuild.2012.07.046}

[4] Enerdata, Odyssee - Energy Efficiency Indicators in Europe, available: http://www.odyssee-

indicators.org/reports/ee_households.php, updated: November 2011 (last viewed January 26, 2012).

[5] R. Hartless, Application of Energy Performance Regulations to Existing Buildings. Final report of the Task B4,

ENPER TEBUC, SAVE 4.1031/C/00-018/2000, Building Research Establishment, Watford, UK, 2003.

[6] C.A. Balaras, E.G. Dascalaki, A.G. Gaglia, K. Droutsa, S. Kontoyiannidis, Energy performance of European buildings, Proceedings of the Energy Sustainability Conference, Long Beach, California, US, July 27-30 (2007) 387396.

[7] Institute Whonen und Umwelt, Use of Building Typologies for Energy Performance Assessment of National Building Stocks. Existent Experiences in European Countries and Common Approach - First TABULA Synthesis Report, Darmstadt, Germany, 2010.

[8] Institute Whonen und Umwelt, Typology Approach for Building Stock Energy Assessment - TABULA, available: http://www.building-typology.eu/, updated: Januar 20, 2012 (last viewed: January 26, 2012).

[9] S. Lechtenböhmer, A. Schüring, The potential for large-scale savings from insulating residential buildings in the EU, Energy Efficiency 4 (2011) 257-270.

[10] C.A. Balaras, K. Droutsa, E. Dascalaki, S. Kontoyiannidis, Heating energy consumption and resulting environmental impact of European apartment buildings, Energy Build. 37 (2005) 429-442.

[11] Danish Enterprise and Construction Authority, Building Regulations 2010 ver. 29.08.2011, http://www.ebst.dk/bygningsreglementet.dk/br10/0/42 (in Danish), (last viewed: March 12, 2012).

[12] G. Verbeeck, H. Hens, Energy savings in retrofitted dwellings: economically viable?, Energy build. 37 (2005) $747-$ 754.

[13] B.S. Darup, Energetische Gebäudesanierung mit Faktor 10 (in German), Deutsche Bundesstiftung Umwelt (DBU), Osnabrück, Germany, 2008.

[14] European Commission, Insulation Measures for Retrofitting of Residential Buildings - THERMIE PROGRAMME ACTION No. B48, 1995.

[15] S. Kamper, A.S. Worm, Energirenovering af Langkærparken (in Danish), Proceedings of Passivhus Norden Conference, Aalborg, Denmark, October 7-8 (2010).

[16] M. Morelli, H. Tommerup, M.K. Tafdrup, S. Svendsen, Holistic energy retrofitting of multi-storey building to low energy level, Proceedings of the 9th Nordic Symposium on Building Physics, NSB 2011, Tampere, Finland, May 29June 2 (2011) 1323-1330. 
REVISED VERSION OF PRE-PRINT

Energy and Buildings, Available online 14 August 2012

DOI: 10.1016/j.enbuild.2012.07.046

[17] Danish Building Research Institute, Be10 version 6: Calculation program for documentation of the energy use in new buildings according to the building regulation 2010, Hørsholm, Denmark, 2011, www.sbi.dk/be10 (last viewed: March 12, 2012).

[18] DS/EN ISO 13790:2008, Thermal performance of buildings - Calculation of energy use for heating and cooling, Danish Standards, Charlottenlund.

[19] T.R. Nielsen, K. Duer, S. Svendsen, Energy performance of glazings and windows, Sol. Energy 69 (2000) 137143.

[20] M. Morelli, S. Svendsen, Investigation of interior post-insulated masonry walls with wooden beam ends, J. Build Phys., doi: 10.1177/1744259112447928 (Published online before print).

[21] H.A. Viitanen, Modelling the Time Factor in the Development of Brown Rot Decay in Pine and Spruce Sapwood The Effect of Critical Humidity and Temperature Conditions, Holzforschung 51 (1997) 99-106.

[22] H.A. Viitanen, Modelling the time factor in the development of mould fungi-The effect of critical humidity and temperature conditions on pine and spruce sapwood, Holzforschung 51 (1997) 6-14.

[23] E. Brandt, E.B. Møller, T. Bunch-Nielsen, G. Christensen, C. Gudum, M.H. Hansen, SBi-anvisning 224: Fugt i bygninger, first ed., Danish Building Research Institute, Aalborg University, Hørsholm, 2009, pp. 58-62 (in Danish). [24] H. Harving, R. Dahl, J. Korsgaard, S.A. Linde, The Indoor Environment in Dwellings: A Study of Air-exchange, Humidity and Pollutants in 115 Danish Residences, Indoor Air 2 (1992) 121-126.

[25] K. Sedlbauer, Prediction of mould growth by hygrothermal calculation, J. Build. Phys. 25 (2002) 321.

[26] G. Branco, B. Lachal, P. Gallinelli, W. Weber, Predicted versus observed heat consumption of a low energy multifamily complex in Switzerland based on long-term experimental data, Energy Build. 36 (2004) 543-555.

[27] H. Hens, W. Parijs, M. Deurinck, Energy consumption for heating and rebound effects, Energy Build. (2010) 105110.

[28] O. Guerra-Santin, L. Itard, The effect of energy performance regulations on energy consumption, Energy Efficiency 2012.

[29] K. Gram-Hanssen, Residential heat comfort practices: understanding users, Build. Res. \& Inf. 38(2) (2010) 175186.

[30] S. Petersen, S. Svendsen, Method for component-based economical optimisation for use in design of new lowenergy buildings, Renewable Energy 38 (2012) 173-180. 


\section{REVISED VERSION OF PRE-PRINT}

Energy and Buildings, Available online 14 August 2012

DOI: 10.1016/j.enbuild.2012.07.046

[31] L. Rønby, T. Kildemoes, H. Tommerup, S.E. Mikkelsen, M.G. Christensen, Erfaringer fra prøvelejlighed Ryesgade 30C 1tv - Delrapport juni 2011 (in Danish), 2011, available:

http://energiplus.net/Dokumenter/Erfaringer_fra_proevelejlighed_Ryesgade_30C_1tv_juli_2011.pdf (last viewed: March 12, 2012). 
REVISED VERSION OF PRE-PRINT

Energy and Buildings, Available online 14 August 2012

DOI: 10.1016/j.enbuild.2012.07.046

Table 1. U- and $\Psi$-values before and after energy retrofitting the building

\begin{tabular}{|c|c|c|c|c|c|}
\hline Component & $\begin{array}{c}U_{\text {before }} \\
W /\left(m^{2} \cdot K\right)\end{array}$ & $\begin{array}{c}U_{\text {after }} \\
W /\left(m^{2} \cdot K\right)\end{array}$ & Assembly & $\begin{array}{c}\Psi_{\text {before }} \\
W /(m \cdot K)\end{array}$ & $\begin{array}{c}\Psi_{\text {after }} \\
W /(m \cdot K)\end{array}$ \\
\hline Masonry wall & 1.20 & 0.33 & Window-wall & 0.16 & 0.15 \\
\hline Spandrel & 2.14 & 0.37 & Outer wall-inner wall & 0.01 & 0.24 \\
\hline End wall & 1.63 & 0.16 & Wall-floor & -0.07 & 0.22 \\
\hline Windows 1 pane & 4.2 & & Wall-roof floor & -0.11 & 0.22 \\
\hline Windows $1+1$ & 2.3 & & Wall-basement floor & -0.54 & -0.11 \\
\hline Floor division & 0.86 & 0.31 & & & \\
\hline New roof structure & - & 0.11 & & & \\
\hline New windows & & 1.03 & & & \\
\hline
\end{tabular}


REVISED VERSION OF PRE-PRINT

Energy and Buildings, Available online 14 August 2012

DOI: 10.1016/j.enbuild.2012.07.046

Table 2. Energy use for the building and heating and hot water

\begin{tabular}{lll}
\hline Energy use & $\begin{array}{l}\text { Measured } \\
\mathrm{kWh} /\left(\mathrm{m}^{2} \text { year }\right)\end{array}$ & $\begin{array}{l}\text { Calculated } \\
\mathrm{kWh} /\left(\mathrm{m}^{2} \text { year }\right)\end{array}$ \\
\hline 2007 heating and hot water & 159.0 & \\
2008 heating and hot water & 160.2 & \\
2009 heating and hot water & 147.3 & 153.0 \\
Average heating and hot water & 155.5 & 162.5 \\
Building's energy use & - & \\
\hline
\end{tabular}


REVISED VERSION OF PRE-PRINT

Energy and Buildings, Available online 14 August 2012

DOI: 10.1016/j.enbuild.2012.07.046

Table 3. Energy data for windows

\begin{tabular}{|c|c|c|c|c|c|}
\hline \# & Window types and retrofit measures & $\begin{array}{l}U_{w} \\
W / m^{2} \cdot K\end{array}$ & $\begin{array}{l}g_{w} \\
-\end{array}$ & $\begin{array}{l}E_{r e f} \\
\mathrm{kWh} /\left(\mathrm{m}^{2} \cdot \text { year }\right)\end{array}$ & $\begin{array}{l}\text { Price incl. VAT } \\
\epsilon\end{array}$ \\
\hline & Reference with 1 layer normal pane & 4.05 & 0.51 & -266 & \\
\hline & Reference with secondary pane (2 panes) & 2.20 & 0.45 & -109 & \\
\hline 1 & Retrofitted with secondary pane ( 3 panes) & 1.09 & 0.38 & -24 & 1485 \\
\hline 2 & Retrofitted with secondary pane ( 2 panes) & 1.62 & 0.44 & -59 & 1315 \\
\hline 3 & Retrofitted with sash on casement ( 2 panes) & 1.76 & 0.44 & -72 & 1615 \\
\hline 4 & New with coupled frames ( 3 panes) & 0.96 & 0.33 & -21 & 1165 \\
\hline 5 & New with coupled frames ( 2 panes) & 1.74 & 0.46 & -67 & \\
\hline
\end{tabular}


REVISED VERSION OF PRE-PRINT

Energy and Buildings, Available online 14 August 2012

DOI: 10.1016/j.enbuild.2012.07.046

Table 4. Measured ventilations rates in test apartment $\left(\mathrm{m}^{3} / \mathrm{h}\right)$

\begin{tabular}{lllll}
\hline & Measured & Measured & Measured & Building \\
Level & Kitchen/exhaust & Bathroom & Total & Regulations \\
\hline 1 & 51 & 40 & 91 & 90 \\
2 & 75 & 51 & 126 & 126 \\
3 & 105 & 75 & 180 & 198 \\
\hline
\end{tabular}


REVISED VERSION OF PRE-PRINT

Energy and Buildings, Available online 14 August 2012

DOI: 10.1016/j.enbuild.2012.07.046

Table 5. Results from noise measurements

\begin{tabular}{llllll}
\hline & $\begin{array}{l}\text { Reverberation, } \\
\text { 500 Hz, } \\
\text { sec. }\end{array}$ & $\begin{array}{l}\text { Background } \\
d B(A)\end{array}$ & Level 1 & Level 2 & Level 3, \\
& & $d B(A)$ & $d B(A)$ & $d B(A)$ \\
\hline Bathroom & 0.3 & 25 & 41 & 48 & 56 \\
Bedroom & 0.5 & 23 & 28 & 32 & 40 \\
Reduction & & & 13 & 16 & 16 \\
\hline
\end{tabular}




\section{REVISED VERSION OF PRE-PRINT}

Energy and Buildings, Available online 14 August 2012

DOI: 10.1016/j.enbuild.2012.07.046

Fig. 1. a) Section and b) plan of the building. The test apartment is marked with a circle. Measurements in meters
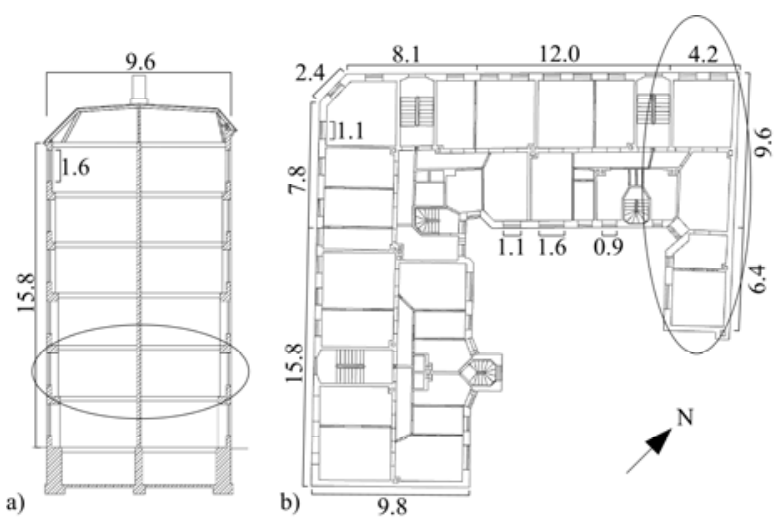

a)

b) 


\section{REVISED VERSION OF PRE-PRINT}

Energy and Buildings, Available online 14 August 2012

DOI: 10.1016/j.enbuild.2012.07.046

Fig. 2. a) Street facade, b) courtyard facade and c) spandrel seen from the apartment
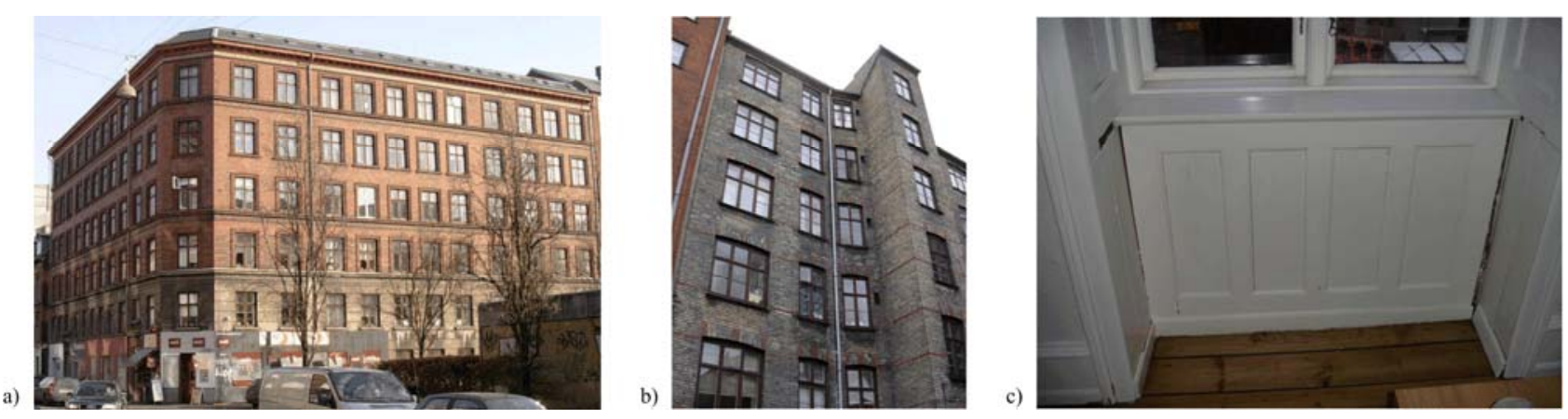
REVISED VERSION OF PRE-PRINT

Energy and Buildings, Available online 14 August 2012

DOI: 10.1016/j.enbuild.2012.07.046

Fig. 3. Plan of test apartment and indication or retrofit measures

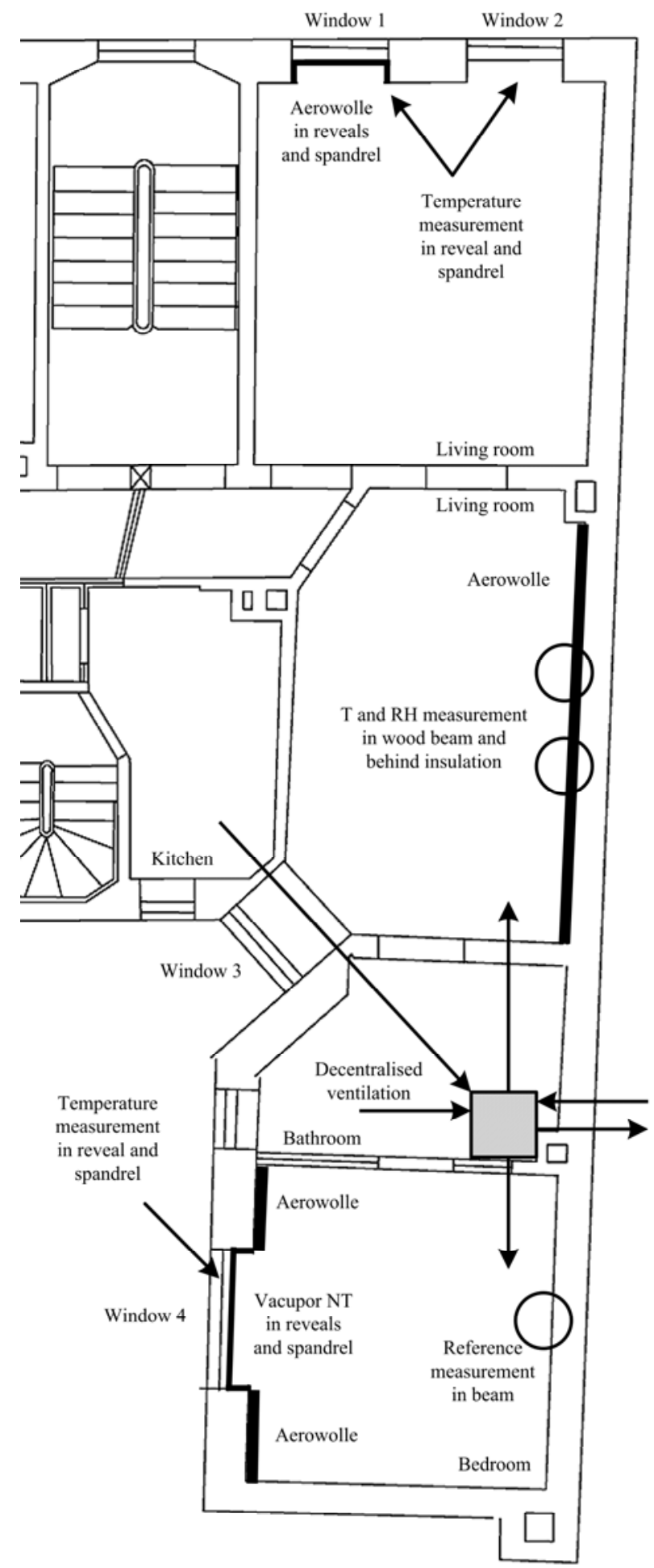




\section{REVISED VERSION OF PRE-PRINT}

Energy and Buildings, Available online 14 August 2012

DOI: 10.1016/j.enbuild.2012.07.046

Fig. 4. Energy retrofitted 4-lite of type Window 2 with a secondary frame seen a) exterior of building and b) interior
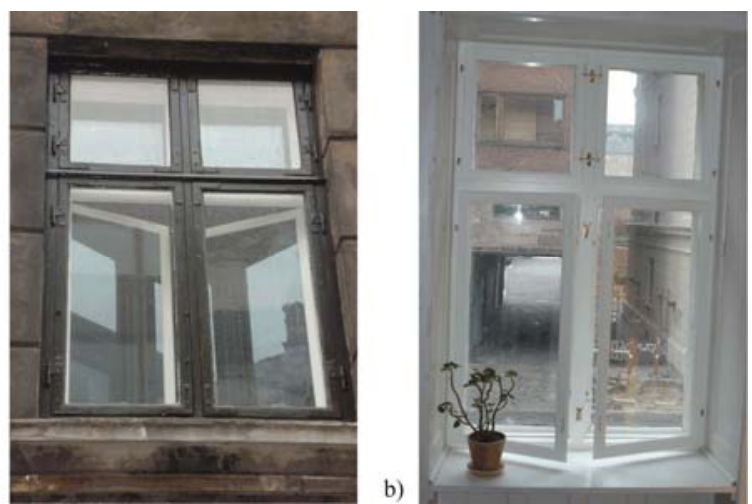


\section{REVISED VERSION OF PRE-PRINT}

Energy and Buildings, Available online 14 August 2012

DOI: 10.1016/j.enbuild.2012.07.046

Fig. 5. a) Horizontal principal section of the frame and casement of Window 1. b) Window 3 with installed sash

a)

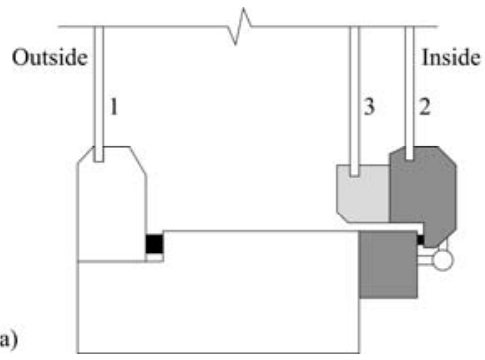

b)

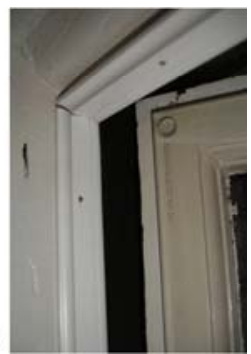




\section{REVISED VERSION OF PRE-PRINT}

Energy and Buildings, Available online 14 August 2012

DOI: 10.1016/j.enbuild.2012.07.046

Fig. 6. a) Horizontal principal section of the frame and casement of Window 4 and 5.b) The new Window 4 seen from the apartment
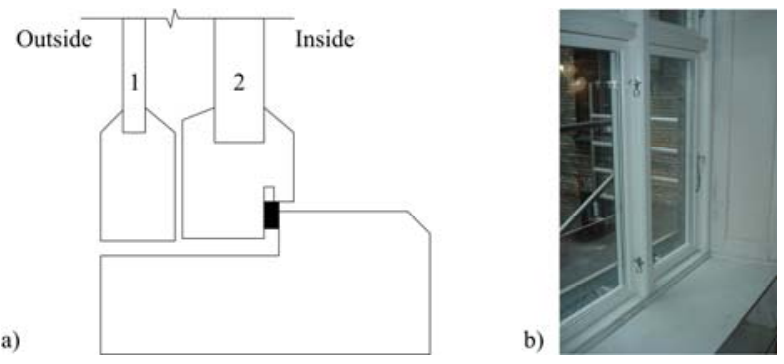


\section{REVISED VERSION OF PRE-PRINT}

Energy and Buildings, Available online 14 August 2012

DOI: 10.1016/j.enbuild.2012.07.046

Fig. 7. Insulation applied in the window reveals where a) is Aerowolle and b) is Vacupor NT

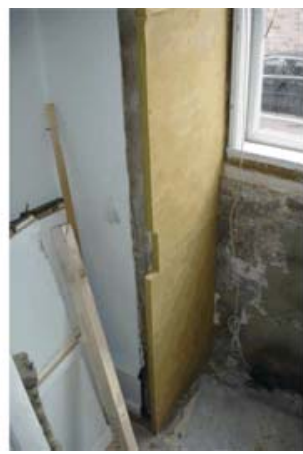

b)

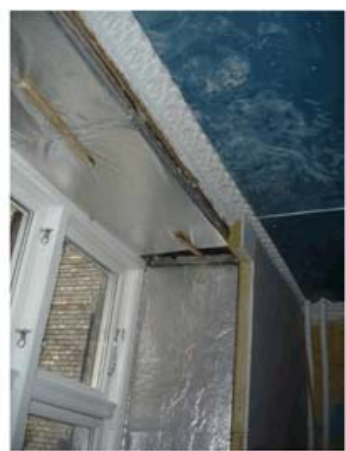




\section{REVISED VERSION OF PRE-PRINT}

Energy and Buildings, Available online 14 August 2012

DOI: 10.1016/j.enbuild.2012.07.046

Fig. 8. Temperature and relative humidity behind inside insulation and relative humidity in room

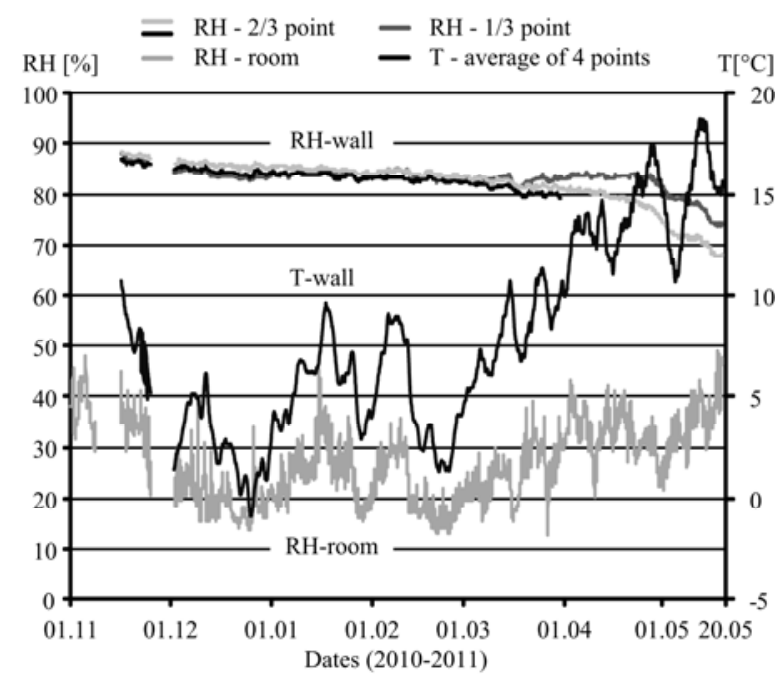




\section{REVISED VERSION OF PRE-PRINT}

Energy and Buildings, Available online 14 August 2012

DOI: 10.1016/j.enbuild.2012.07.046

Fig. 9. Thermal imaging of the a) singe pane reference window and b-e) the four investigated Windows 1-4

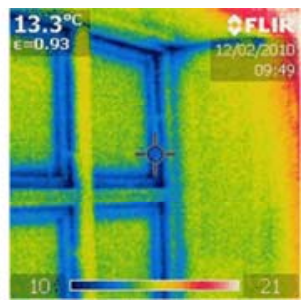




\section{REVISED VERSION OF PRE-PRINT}

Energy and Buildings, Available online 14 August 2012

DOI: 10.1016/j.enbuild.2012.07.046

Fig. 10. Ventilation ducts in apartment. a) Inlet and outlet from the air handling unit; b) duct located in rooms

a)
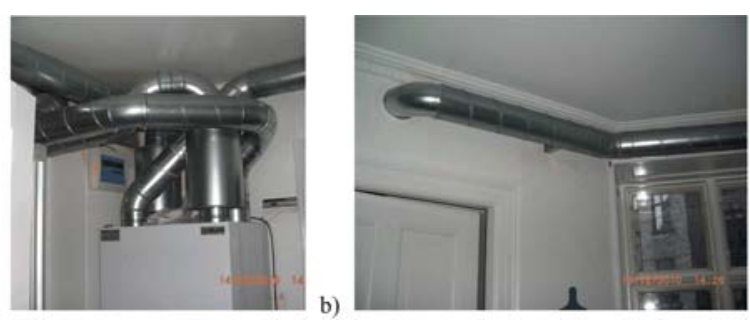
REVISED VERSION OF PRE-PRINT

Energy and Buildings, Available online 14 August 2012

DOI: 10.1016/j.enbuild.2012.07.046

Fig. 11. Energy use and savings for building envelope measures

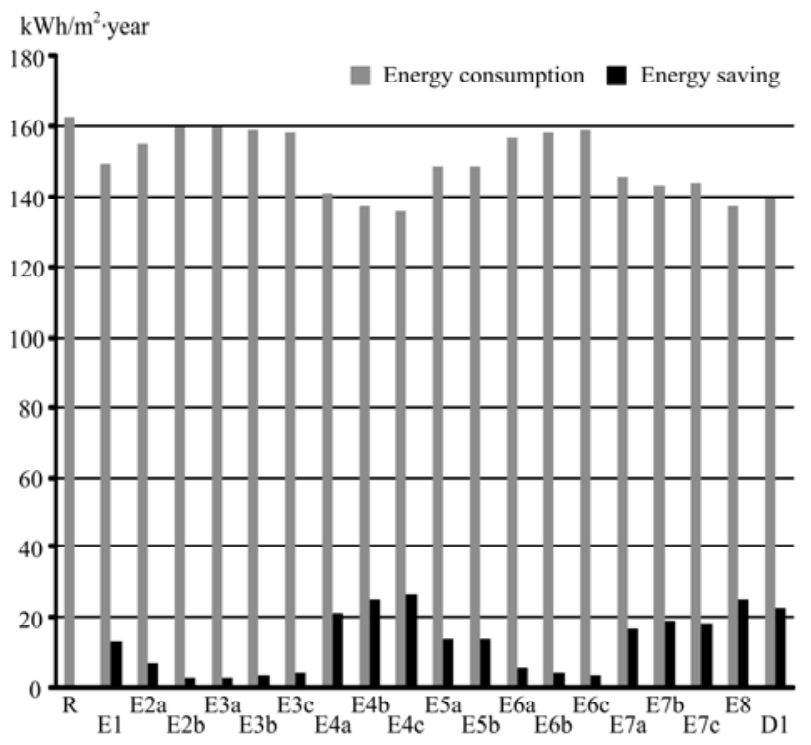

R: Existing building

E1: End wal, $250 \mathrm{~mm}$ outside insulation

E2a: Ceiling to attic, injection of $100 \mathrm{~mm}$ insulation

E2b: New insulated roof construction, average insulation $350 \mathrm{~mm}$

E3a: Floor to the basement, $50 \mathrm{~mm}$ mineral wool

E3b: Floor to the basement, $100 \mathrm{~mm}$ mineral wool

E3c: Floor to the basement, $150 \mathrm{~mm}$ mineral wool

E4a: Window, retrofitted as window 2

E4b: Window, retrofitted as window 1

E4c: Window, new as window 4

E5a: Spandrel, injection of $100 \mathrm{~mm}$ insulation

E5b: Spandrel, $40 \mathrm{~mm}$ Aerowolle

E6a: Window reveal, $20 \mathrm{~mm}$ Vacupor NT

E6b: Window reveal, $20 \mathrm{~mm}$ Aerowolle

E6c: Window reveal, $20 \mathrm{~mm}$ mineral wool

E7a: Wall, $70 \mathrm{~mm}$ inside mineral wool insulation

E7b: Wall, $100 \mathrm{~mm}$ inside mineral wool insulation

E7c: Wall, $40 \mathrm{~mm}$ inside Aerowolle

E8: Wall, spandrel and window reveal, Aerowolle combination

D1: Roof dwellings, $350 \mathrm{~mm}$ insulation and increased heated floor area 
REVISED VERSION OF PRE-PRINT

Energy and Buildings, Available online 14 August 2012

DOI: 10.1016/j.enbuild.2012.07.046

Fig. 12. Energy use and savings for mechanical equipment measures

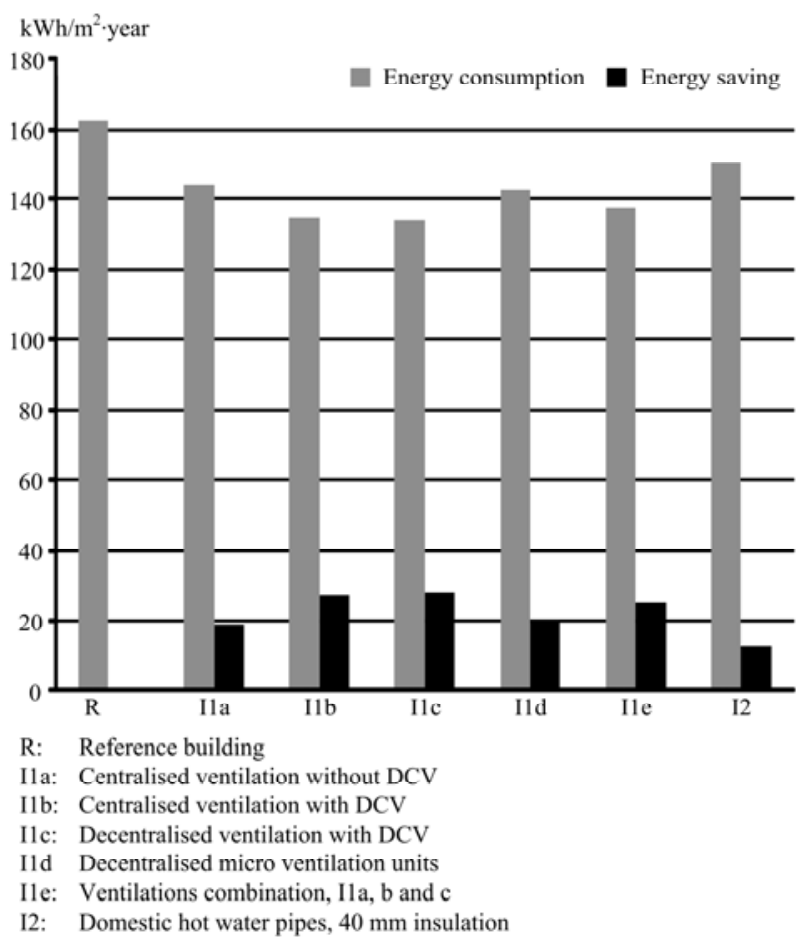




\section{REVISED VERSION OF PRE-PRINT}

Energy and Buildings, Available online 14 August 2012

DOI: 10.1016/j.enbuild.2012.07.046

Fig. 13. Energy use before and after whole building retrofitting

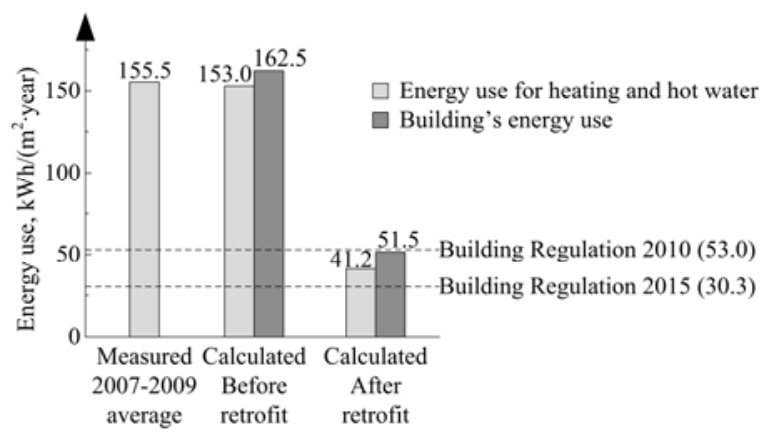

